\title{
The impact of phenomena EI Niño and La Niña and other environmental factors on episodes of acute diarrhoea disease in the population of Aguascalientes, Mexico: a case study
}

\author{
Martha Esthela Venegas-Pérez ${ }^{1}$, Elsa Marcela Ramírez-López ${ }^{1}$, Armando López-Santos ${ }^{2}$, \\ Víctor Orlando Magaña-Rueda ${ }^{3}$, and Francisco Javier Avelar-González ${ }^{1}$ \\ ${ }^{1}$ Biochemical Engineering Department/Physiology and Pharmacology Department, Universidad Autónoma de \\ Aguascalientes, Aguascalientes, México \\ ${ }^{2}$ Unidad Regional Universitaria de Zonas Áridas, Universidad Autónoma Chapingo, Bermejillo, Durango, México \\ ${ }^{3}$ Center for Atmospheric Sciences, Universidad Nacional Autónoma de México, Distrito Federal, México
}

Correspondence to: Elsa Marcela Ramírez-López (emramir@ correo.uaa.mx)

Received: 12 December 2015 - Revised: 9 February 2016 - Accepted: 15 February 2016 - Published: 8 March 2016

\begin{abstract}
Acute diarrhoea diseases (ADDs) are one of the major health problems in Aguascalientes, Mexico. Due to the risk of significant increases of ADDs in the hot season, it has been necessary to determine the weather conditions that might lead to escalating ADD events. The effects of El Niño and La Niña phenomena on the morbidity rate of ADD (MRADD) in the State of Aguascalientes were determined during the period of 2000-2010. The MRADD was calculated from cases reported by the State Health Department. The Oceanic Niño Index (ONI) was obtained from the US National Oceanic and Atmospheric Administration. The impact of El Niño and La Niña on the MRADD was determined using the Pearson correlation coefficient and analysis of variance (ANOVA). The results gave a significant inverse correlation between El Niño phenomenon and MRADD $(r=$ $-0.55, P=0.001$ ), but a correlation was not observed on the La Niña phenomenon $(r=-0.022, P=0.888)$. Field data showed significant inverse influence of El Niño on MRADD for the years 2000-2010.
\end{abstract}

\section{Introduction}

Several authors have investigated the ways in which El Niño Southern Oscillation (ENSO) has occurred in Mexico. The main consequences of El Niño phenomenon in Mexico are the intensification of winter rainfall in the northwest and northeast of Mexico while decreasing toward the south.
ENSO has produced colder winters and drier and warmer summers often producing severe droughts.

Several studies have shown a potential impact of ENSO on human health with vector-borne diseases (Schaffner and Mathis, 2014) and with acute diarrhoea diseases (ADDs) (Patz and Olson, 2006). These studies agree that the ENSO can increase the ambient temperature that could enhance the survival and persistence of many microorganisms causing ADDs because microorganisms can reproduce faster in warmer conditions.

Subsequent studies have shown that climatic factors significantly affect seasonal diarrhoea in susceptible populations (El-Fadel et al., 2012).

Global deaths of children aged less than 5 years from diarrhoea were estimated at 1.87 million (95\% confidence interval, CI: $1.56-2.19)$, approximately $19 \%$ of total child deaths. WHO African and South-East Asia Regions combined showed $78 \%$ (1.46 million) of all diarrhoea deaths occurring among children in the developing world; $73 \%$ of these deaths occurred in 15 developing countries (BoschiPinto et al., 2008).

In Mexico, the recorded mortality rate of ADDs was 28 deaths in 2013 and 16519 new cases per 100000 children under one year of age were also reported. Moreover, 266 deaths were registered with a rate of 3.5 per 100000 children among 1 to 4 years of age. The ADDs were the fifth cause of death in this age group. 
In the state of Aguascalientes, ADDs were the fifth leading cause of infant death in the year 2013 (ISEA, 2014). It has been estimated that children under 5 years of age can experience between two to four diarrhoeal episodes per year.

According to Hernández (2002) and Ferrano et al. (2003) the age groups that are most affected by ADDs are the small children (under 5 years) and the elderly (over 60 years), who are more sensitive to suffer the effects due to excessive loss of electrolytes affecting the body during illness and can cause severe dehydration (Hernández et al., 2011).

The aim of this study was to determine the impact of El Niño and La Niña phenomena on the ADDs as well as other possible environmental factors during the period 2000-2010 in the population of the state of Aguascalientes, Mexico.

\section{Data and methods}

\subsection{Area of study}

The geographical unit of the study consisted of the State of Aguascalientes located in central Mexico

with geographic coordinates $22^{\circ} 27^{\prime} 36^{\prime \prime} \mathrm{N}, 21^{\circ} 37^{\prime} 12^{\prime \prime} \mathrm{S}$ of north latitude and $101^{\circ} 50^{\prime} 05^{\prime \prime} \mathrm{E}, 102^{\circ} 52^{\prime} 41^{\prime \prime} \mathrm{W}$ of west longitude (INEGI, 2014). It has a surface of $5616 \mathrm{~km}^{2}$. The state of Aguascalientes represents $0.3 \%$ of the Mexican surface area. Three major natural regions through its territory include the Sierra Madre Occidental, the Central Mesa or Plateau and Neovolcanic. The territory of the state is predominantly flat. The State is comprised of eleven municipalities with a total of 1184996 inhabitants (INEGI, 2010) concentrating $67 \%$ of the population in the City of Aguascalientes. The climate prevailing in the state is semi-dry in $86 \%$ of its territory, $14 \%$ humid temperate is localized southwest and northwest of the state. The average annual temperature is $17-18^{\circ} \mathrm{C}$. The highest temperature $\left(30^{\circ} \mathrm{C}\right.$ or more) occurs in the months of May and June and the lowest temperature (about $4{ }^{\circ} \mathrm{C}$ ) in January. Rain is limited and occurs during the summer. Total annual precipitation is $526 \mathrm{~mm}$ (INEGI, 2010).

\subsection{ADDs database}

Information on the number of cases of more frequent and representative in the state of Aguascalientes was obtained from the Aguascalientes State Health Institute (ISEA, Spanish acronym). Data also included information on intestinal infections by other organisms and ill-defined with ICD 10 code: A04, A08-A09. The A04 code includes intestinal bacterial infections due Escherichia coli: enteropathogenic, enterotoxigenic, enterohemorrhagic and enteroinvasive, Campylobacter Spp., Yersinia enterocolitica, and Clostridium difficile. The A08 code includes intestinal infections caused by viruses and other specified bodies: Rotavirus, Norwalk agent, and Adenovirus. The A09 code includes diarrhoea and gastroenteritis of presumed infectious origin. This information pertained for all the groups of 0-4 years, 5-59 years and above
60 years of age. Cases of ADDs included both men and women. The ADD rates were calculated dividing the numbers of episodes reported between the numbers of the annual population to express morbidity rates per 10000 habitants. An ecological time-series study was also conducted.

\subsection{El Niño and La Niña database}

The information of the Oscillation El Niño Index (ONI) was obtained from the US National Oceanic and Atmospheric Administration (NOAA) for the period 2000-2010 (NOAA, 2014). This oceanic index defined the presence of El Niño with at least five successive overlapping three-month seasons experiencing sea surface temperature decreases of more than $0.5^{\circ} \mathrm{C}$; was defined as "La Niña" the consecutive presence of five or more values less than $-0.5^{\circ} \mathrm{C}$.

\subsection{Climate database}

The daily weather variables of maximum temperature and precipitation were obtained from eighteen weather stations of the National Water Commission (CONAGUA, Spanish acronym). The period was from 2000 to 2010 . Data quality control considered that $96 \%$ of annual records were present in the time series of which was obtained the average of monthly maximum temperature and accumulated rainfall.

\subsection{Statistical analysis}

The statistical processing was performed with the statistical software Minitab $^{\circledR}$ 16.2.3 (Minitab Inc., State College, PA). Descriptive statistics based on the calculation of measures of central tendency and the dispersion was performed. To correlate the phenomena under study with the rate of ADDs, the Pearson correlation coefficients were obtained, as well as to analyze the association between ADD with ONI and the number of days with temperature $\geq 30^{\circ} \mathrm{C}$ and the number days with non-zero precipitation.

\section{Results}

\subsection{Oscillation Niño Index and El Niño and La Niña phenomena}

During the decade of the study, there was a total of four El Niño events, which were initiated between the months of May and August of the years 2002, 2004, 2006 and 2009, and extended to the autumn of the following year $(2003,2005$, 2007 and 2010, respectively). According to the analysis of ONI, two of them were mild (2004 and 2006) and two with moderate intensity (2002 and 2009); ONI maximum values were reached in December $2009(\mathrm{ONI}=1.6)$ as well as in November and December of $2002(\mathrm{ONI}=1.3)$.

There was a total of five La Niña events. The first La Niña event began in July 1998 and continued until Febru- 
ary 2001. The second and the fourth began in November and ended in March of the years 2005-2006 and 2008-2009. The third event occurred in August 2007 and continued until June 2008. The fifth event began in July 2010 and ended in April 2011. The latter phenomenon had strong intensity. The first and the third events varied in intensity between strong and moderate while the second and fourth events had weak intensities.

The lowest values of ONI were for the events that occurred in January and February 2000 (with values of -1.7 and -1.5 respectively), January and February 2008 and October, November and December 2010 ( -1.5 in all cases).

\subsection{Analysis of EI Niño and La Niña phenomenon for those days with temperature above $30^{\circ} \mathrm{C}$ and with nonzero precipitation}

The average maximum temperature ranged between 20.1 and $32.4^{\circ} \mathrm{C}$, the average minimum temperature between 1.9 and $13.5^{\circ} \mathrm{C}$ and the average rainfall from 0 to $252.2 \mathrm{~mm}$. The warmest month was June and the coldest January. These results were based on the weather information for the state of a 31 year-period (1970 to 2010). As shown in Fig. 1, the number of days at or above temperatures of $30^{\circ} \mathrm{C}$ in Aguascalientes, Mexico, showed a steadily and linear increase from 2000 to 2010 and the maximum values of days with temperatures at or above the 90 th percentile $\left(30^{\circ} \mathrm{C}\right)$ were reached in 2009 .

The correlation was sought between the phenomenon $\mathrm{El}$ Niño with the number of days with temperatures above $30^{\circ} \mathrm{C}$ (90 percentile) and found that there was indeed significant inverse correlation $(r=-0.430, P=0.014)$. We did not find a correlation between phenomenon La Niña and the number of days with temperatures at or above $30^{\circ} \mathrm{C}(r=-0.228$, $P=0.146)$.

The rainfall pattern was other climate element in Aguascalientes that observed significant changes in atmospheric behaviour. Weather seasons were defined by the peculiarities of rainfall in the state: the rainy season which extended from May to October and the dry season from November to April (Fig. 2).

\subsection{ADD analysis for children under 5 years of age}

In the period 2000-2010, the average rate of ADD statewide was 20.07 episodes per 10000 people. This ADD rate was similar to that presented in neutral conditions and during El Niño events (20.46 and 20.25 episodes per 10000 inhabitants, respectively). During La Niña, there were 18.06 episodes per 10000 inhabitants which was lower than the ADD rate obtained in neutral conditions or El Niño events, although no significant difference was found (Table 1).

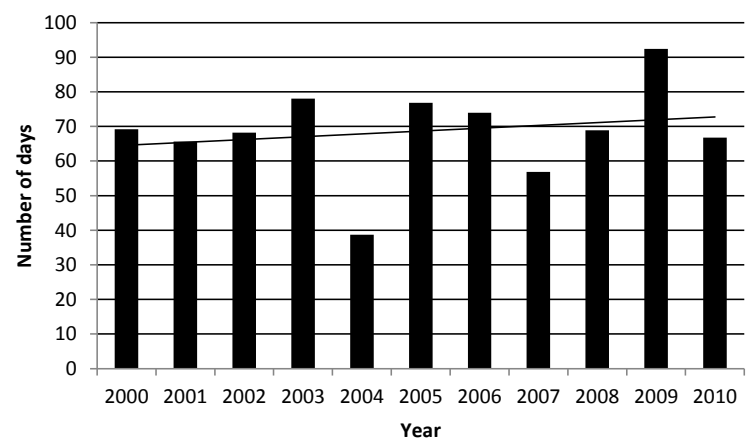

Figure 1. Number of days with temperatures above $30^{\circ} \mathrm{C}$ (90th percentile) on Aguascalientes, Mexico.

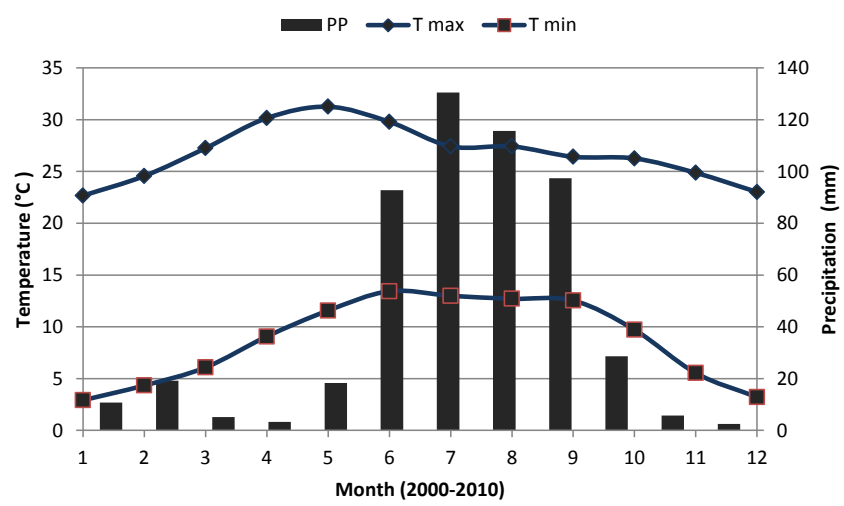

Figure 2. Climograph of Aguascalientes, Mexico for the period 2000-2010.

\subsection{ADD Analysis for the population aged 5 and older}

In the period 2000-2010, the morbidity of ADD varied between 107.40 and 25.90 episodes per 10000 inhabitants. The highest rates were reported in June 2008 (70.16 events per 10000 inhabitants) and from April to August 2010 (85.12, $103.32,107.40,95.98$ and 76.53 episodes per 10000 inhabitants, respectively).

During the observed phenomena, the rate of ADD in El Niño conditions was 44.37 episodes per 10000 habitants. In neutral conditions, the ADD rate was 46.33 episodes per 10000 inhabitants, and during La Nina phenomenon the ADD rate was 41.41 episodes per 10000 inhabitants. To correlate the morbidity of ADD with ONI, a significant correlation (Table 2) was observed for the three age groups. In the case of La Niña and neutral conditions no correlation was found with ONI.

The incubation time that the ADD causing microorganism has before the disease symptoms appear are evident. There are time lags of several weeks, one month that may interfere with the interpretation of the quality of the relationship cause-effect between climate variables and ADD.

It is noteworthy to mention that when heavy rain falls after a prolonged drought, ADDs may significantly increase due 
Table 1. Description of diarrhoea diseases by age and El Niño, La Niña and neutral from 2000 to 2010.

\begin{tabular}{lrrrr}
\hline & $\begin{array}{r}\text { El Niño phenomenon } \\
\text { Mean } \pm \text { SD }\end{array}$ & $\begin{array}{r}\text { La Niña phenomenon } \\
\text { Mean } \pm \text { SD }\end{array}$ & $\begin{array}{r}\text { Neutral Condition } \\
\text { Mean } \pm \text { SD }\end{array}$ & $P$ value* \\
\hline Children under 5 years & $20.25 \pm 6.37$ & $18.06 \pm 5.48$ & $20.46 \pm 4.50$ & 0.000 \\
People 5 to 59 years & $44.37 \pm 14.36$ & $41.41 \pm 13.78$ & $46.33 \pm 10.94$ & 0.001 \\
Adults over 60 years & $3.86 \pm 1.4$ & $3.64 \pm 1.23$ & $4.0 \pm 0.82$ & 0.001 \\
\hline
\end{tabular}

* Test of Levene

Table 2. Spearman's correlation analysis between diarrhoea diseases and El Niño, La Niña and neutral conditions in Aguascalientes, Mexico from 2000-2010.

\begin{tabular}{lllrrr}
\hline & Lag & & $\begin{array}{r}\text { Children } \\
\text { under 5 years }\end{array}$ & $\begin{array}{r}\text { People } \\
5 \text { to 59 years }\end{array}$ & $\begin{array}{r}\text { Adults } \\
\text { over 60 years }\end{array}$ \\
\hline \multirow{2}{*}{ La Niña phenomenon } & \multirow{2}{*}{0 month } & Coefficient & 0.361 & 0.154 & 0.101 \\
& & $P$ value & 0.019 & 0.329 & 0.523 \\
\cline { 2 - 6 } & \multirow{2}{*}{1 month } & Coefficient & 0.491 & 0.32 & 0.287 \\
& & $P$ value & 0.001 & 0.03 & 0.108 \\
\hline \multirow{2}{*}{ El Niño phenomenon } & \multirow{2}{*}{0 month } & Coefficient & -0.648 & -0.552 & -0.453 \\
& & $P$ value & 0.000 & 0.001 & 0.009 \\
\cline { 2 - 6 } & \multirow{2}{*}{1 month } & Coefficient & -0.482 & -0.45 & -0.263 \\
& & $P$ value & 0.001 & 0.051 & 0.019 \\
\hline \multirow{2}{*}{ Neutral Conditions } & \multirow{2}{*}{0 month } & Coefficient & -0.079 & -0.054 & -0.041 \\
& & $P$ value & 0.59 & 0.711 & 0.778 \\
\cline { 2 - 5 } & \multirow{2}{*}{1 month } & Coefficient & -0.034 & 0.058 & 0.100 \\
& & $P$ value & 0.817 & 0.691 & 0.493 \\
\hline
\end{tabular}

to the presence of microorganisms in water bodies. Figure 3 shows a significant increase in the number of ADDs occurrences in 2010 most probably due to heavy rain events in 2008 and 2010 with a prolonged drought in between those years in 2009. The number of ADDs occurrences in 2010 was greater than in 2008 and 2009 (Table 3).

\subsection{Analyses of the correlation between the number of days with temperatures over $30^{\circ} \mathrm{C}$, and EI Niño and La Niña phenomena and the rate of ADD}

By relating the phenomenon El Niño with the number of days with temperatures above the 90 th percentile $\left(30^{\circ} \mathrm{C}\right)$, it was observed a significant inverse correlation with the increase of days. A significant direct correlation between the rates of ADDs were also determined (Table 4).

\section{Discussion}

In the 2000-2010 period, a correlation of the number of days with non-zero precipitation with the morbidity of ADDs was determined for all three age groups (under 5, 5 to 59 and over 60 years). But no correlation was found with La Niña phenomenon, or under neutral conditions (Table 2).

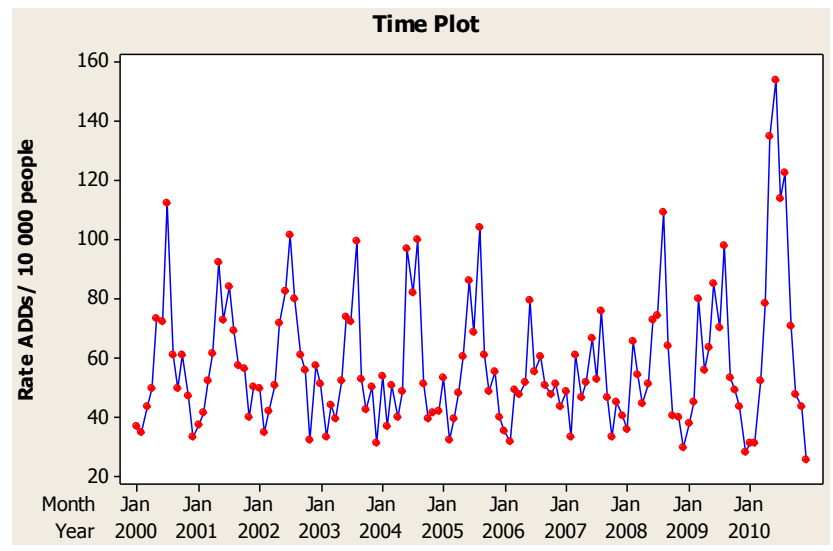

Figure 3. Time Plot rate ADDs.

Although these results do not imply a relationship causeeffect between climate variables and phenomena studied, the results suggest that both the disease and weather are seasonal events. These results also indicate that studies of the correlations between human diseases and weather are important and should be further investigated, as any variation of scale 
Table 3. Correlations between diarrhoea diseases and ONI in Aguascalientes from 2009 to 2010 after one heavy rain (2009) a strong drought (2010).

\begin{tabular}{lllrrr}
\hline & Lag & & $\begin{array}{r}\text { Children } \\
\text { under 5 years }\end{array}$ & $\begin{array}{r}\text { People } \\
5 \text { to 59 years }\end{array}$ & $\begin{array}{r}\text { Adults } \\
\text { over 60 years }\end{array}$ \\
\hline \multirow{2}{*}{ La Niña Phenomenon } & \multirow{2}{*}{ m month } & Coefficient & 0.552 & 0.527 & 0.511 \\
& & $P$ value & 0.001 & 0.051 & 0.020 \\
\cline { 2 - 6 } & \multirow{2}{*}{1 month } & Coefficient & 0.620 & 0.451 & 0.370 \\
& & $P$ value & 0.008 & 0.060 & 0.010 \\
\hline \multirow{2}{*}{ El Niño Phenomenon } & \multirow{2}{*}{0 month } & Coefficient & -0.82 & -1.459 & -0.326 \\
& & $P$ value & 0.004 & 0.182 & 0.058 \\
\cline { 2 - 6 } & \multirow{2}{*}{1 month } & Coefficient & -0.626 & -0.128 & -0.003 \\
& & $P$ value & 0.053 & 0.724 & 0.090 \\
\hline
\end{tabular}

Table 4. Spearman's correlation analysis between diarrhoea diseases and total days with temperatures above $30^{\circ} \mathrm{C}$ and days with precipitation nonzero in Aguascalientes, Mexico from 2000-2010.

\begin{tabular}{|c|c|c|c|c|c|c|}
\hline & \multicolumn{2}{|c|}{$\begin{array}{c}\text { El Niño Phenomenon } \\
\text { number of days } T>=30^{\circ} \mathrm{C}\end{array}$} & \multicolumn{2}{|c|}{$\begin{array}{c}\text { La Niña Phenomenon } \\
\text { number of days } P_{p}>0 \mathrm{~mm}\end{array}$} & \multicolumn{2}{|c|}{$\begin{array}{c}\text { Neutral Condition } \\
\text { number of days } P_{p}>0 \mathrm{~mm}\end{array}$} \\
\hline & Coefficient & $P$ value & Coefficient & $P$ value & Coefficient & $P$ value \\
\hline Children under 5 years & 0.573 & 0.001 & 0.663 & 0.000 & 0.430 & 0.001 \\
\hline People 5 to 59 years & 0.763 & 0.000 & 0.714 & 0.000 & 0.603 & 0.000 \\
\hline Adults over 60 years & 0.800 & 0.000 & 0.626 & 0.000 & 0.620 & 0.000 \\
\hline condition & -0.339 & 0.018 & 0.251 & 0.031 & 0.029 & 0.468 \\
\hline
\end{tabular}

in weather patterns would bring seasonal variations in epidemiological patterns.

Similar to other studies that have shown statistical correlations between El Niño and ADDs, the results from this study are in agreement with previous investigations. We observed a morbidity rate increased with an increase in the number of days with temperatures above $30^{\circ} \mathrm{C}$, which occurred under conditions of El Niño phenomenon causing the higher rate of morbidity than the state average under neutral conditions or La Niña phenomenon. This effect is consistent with that observed in the three groups of people in the state of Aguascalientes, Mexico.

Higher temperatures increase the risk of exposure of people to parasitic and bacterial diarrhoea and lengthen the survival of enterotoxigenic Escherichia coli bacteria in contaminated food (Black and Lanata, 1995; Checkley et al., 2000). Low temperatures increase the transmission of diarrhoea caused by viruses (Konno et al., 1995) and at intermediate temperatures $\left(18-23^{\circ} \mathrm{C}\right)$, children may be exposed to viral pathogens, bacteria, and protozoa (Checkley et al., 2000).

Something that is worth mentioning is the fact that approximately $96 \%$ of treated and raw sewage generated by the various sectors of the State is directly discharged to the San Pedro River (Anónymous, 2007; Ramírez et al., 2007). In a previous study conducted by Guzmán-Colis et al. (2011), it was found that water from the San Pedro River showed average concentrations of faecal coliform, about $3.16 \times 106 \mathrm{MPN} / 100 \mathrm{~mL}$, which exceeded four orders of magnitude the maximum limit.

Regarding the resistance of Escherichia coli than were present in this river; Ramírez-Castillo et al. (2013) found that $52 \%$ of the strains were resistant to at least one antimicrobial agent, at least $37.3 \%$ resistant to two agents, and $30.6 \%$ were multi-resistant to multiple drugs. Twelve strains were also resistant to the fluoroquinolone and presented a multi-resistant phenotype.

It is important to mention that the waters of the San Pedro River are directly used for irrigation of vegetables, as well as a source of drinking water for animal's farms nearby to this river. The contamination of the San Pedro River can be a source of bacterial contamination for people and animals, either directly or indirectly through contact to water droplets that evaporate or by the direct consumption of vegetables.

Other studies have found a strain of E. coli O157: $\mathrm{H} 7$ in fruits and vegetables such as lettuce, radish and alfalfa (Bier, 1991; Como-Sabetti et al., 1997; Hilborn et al., 1999).

The ability of these bacteria to survive outside a host or in wet conditions was evaluated by various researchers to determine the possibility that they could survive in the atmosphere. For example, Rose et al. (1997) successfully isolated the bacterium Escherichia coli in various samples of ur- 
ban dust in Mexico City and varied atmospheric conditions. Bautista-Olivas et al. (2013) found colonies of total coliforms and faecal coliforms in atmospheric water condensed in three areas of Mexico. Although the weather conditions of the state of Aguascalientes differ from the studied areas, these results suggest the $E$. coli bacteria can survive in the water from the atmosphere and environmental dust (under wet conditions and warm temperatures). This outcome suggests a potential for contamination and other pathogenic bacteria under these weather conditions.

Another probable line of transmission of $E$. coli bacteria could be the housefly (Musca domestica) as Béjar et al. (2006) showed that the housefly acts as a mechanical vector of enteropathogenic Escherichia coli. The presence of these bacteria was also diagnosed, among others, on dozens of species of cockroaches (Boschi-Pinto et al., 2008). The impact of these findings is enhanced by the fact that the propagation of these vectors with increased temperatures results in a greater chance of developing diarrhoea (Dakshinamurty, 1948; Abdullah, 1961).

The reproduction dynamics and mobility of insects along with the increase of days with temperatures above $30^{\circ} \mathrm{C}$ can cause the appearance of new vector breeding sites on the banks of rivers and dams. Ambient temperatures exceeding the 90th percentile in rivers and dams can show a decrease in flow. Added heavy rains can cause the formation of new hatcheries that are quickly colonized. It is highly likely that these causes and effects have a high impact on increasing confirmed cases of ADD under El Niño in the population of the state of Aguascalientes.

On the other hand, the increase in the number of days with temperatures above the 90th percentile and behaviour patterns that are more common during warm season; such as increased water demand and little awareness hygiene practices climates (Black and Lanata, 1995; Checkley et al., 2000) and socioeconomic factors (Guerrant et al., 2002; Loyola and Soncco, 2007) such as access to water and sanitation services contribute to increased rates of diarrhoea.

The increase in morbidity of EDAs by E. coli in Aguascalientes was associated with an increase in days with higher ambient temperature above the 90th percentile, and these are exacerbated by the El Niño phenomenon.

Understanding the effect of climate variability on the epidemiology of the disease is necessary to take measures in the centre of health care to prevent or reduce the incidence of these diarrhoeal diseases and health education. Also, it is necessary to reinforce appropriate ADD preventive and treatment practices among parents and caregivers of children $<5$ years of age.

Further studies for the collection of information such as social, economic, cultural and health areas and household conditions are needed. More studies are suggested to complete the total environment (socioeconomic, environmental, immunological and epidemiological) that accounts for disease dynamics in the study area and to be better prepared for future changes in climate caused by the intense El Niño events.

\section{Conclusion}

Meteorological and epidemiological data from the period 2000-2010 have shown a correlation between El Niño and ADDs, showing a morbidity rate increased by the increase in the number of days with temperatures above $30^{\circ} \mathrm{C}$, which occurred under conditions of El Niño phenomenon. But no correlation between rates of ADDs and La Niña or neutral conditions were found. The main constraint is associated with the lack of accurate and long term monitoring data on occurrences of ADD, especially related to differentiation among various causes, social and economic classes and environmental factors. Equally significant, the approach adopted in this study is based on the assumption that current associations will remain unchanged in the future which might introduce uncertainties because biological acclimatization as well as technologic and socio-economic developments will likely influence population vulnerability and exposure-response relationships.

Author contributions. M. E. Venegas-Pérez prepared the manuscript with contributions from all co-authors, E. M. RamírezLópez and V. O. Magaña-Rueda Co-tutors of dissertation and reviewers and contributors to the paper, A. López-Santos and F. J. Avelar-González assessors of dissertation and reviewers and contributors to the paper.

Acknowledgements. Authors acknowledge CONACyT for the scholarship to develop a PhD program in Biological Sciences. Special acknowledgements to SEMARNAT-CONACyT (S00102008-1) for the financial support to conduct this study.

Edited by: J. D. Pabón-Caicedo

Reviewed by: A. R. Moreno and A. Hildebrandal

\section{References}

Abdullah, M.: Behavioural effects of temperature on insects, Ohi J. Sci., 61, 212-219, 1961.

Anónymous: Comisión Nacional del Agua (CONAGUA), Estadísticas del agua en México, Secretaría de Medio Ambiente y Recursos Naturales, México, DF, 626 pp., 2007.

Bautista Olivas, A. L., Tovar Salinas, J. L., Mancilla Villa, Ó. R., Magdaleno Flores, H., Ramírez Ayala, C., Arteaga Ramírez, R., and Vázquez Peña, M. A.: Calidad microbiológica del agua obtenida por condensación de la atmósfera en Tlaxcala, Hidalgo y Ciudad de México, Rev. Int. Contam. Ambie, 29, 167-175, 2013. 
Béjar, V., Chumpitaz, J., Pareja, E., Valencia, E., Huamán, A., Sevilla, C., Tapia, M., and Saez, G.: Musca domestica como vector mecánico de bacterias enteropatógenas en mercados y basurales de Lima y Callao, Revista Peruana de Medicina Experimental y Salud Publica, 23, 39-43, 2006.

Bier, J. W.: Isolation of parasites on fruits and vegetables, Sotuheast Asian, J. Trop. Med. Pub. Health., 22, 144-145, 1991.

Black, R. E. and Lanata, C. F.: Epidemiology of diarrheal diseases in developing countries, in: Infections of the gastrointestinal tract, edited by: Blaster, M. J., Smith, P. D., Ravdin, J. I., Greenberg, H. B., and Guerrant, R. I., Raven Press, New York, 13-16, 1995.

Boschi-Pinto, C., Velebit, L., and Shibuya, K.: Estimating child mortality due to diarrhoea in developing countries, B. World Health Organ., 86, 710-717, 2008.

Checkley, W., Epstein, L. D., Gilman, R. H., Figueroa, D., Cama, R. I., Patz, J. A., and Black, R. E.: Effects of EI Niño and ambient temperature on hospital admissions for diarrhoeal diseases in Peruvian children, The Lancet, 355, 442-450, 2000.

Como-Sabetti, K., Allaire, S., Parrott, K., Simonds, C. M., Hrabowy, S., Ritter, B., Hall, W., Altamirano, J., Martin, R., Downes, F., Jennings, G., Barrie, R., Dorman, M. F., Keon, N., Kucab, M., Al Shab, A., Robinson-Dunn, B., Dietrich, S., Moshur, L., Reese, L., Smith, J., Wilcox, K., Tilden, J., Wojtala, G., Park, J. D., Winnett, M., Petrilack, L., Vasquez, L., Jenkins, S., Barrett, E., Linn, M., Woolard, D., Hackler, D. R., Martin, H., McWilliams, D., Rouse, B., Willis, S., Rullan, J., Miller, Jr., G., Henderson, S., Pearson, J., Beers, J., Davis, R., and Saunders, D.:: Outbreaks of Escherichia coli O157: H7 infection associated with eating alfalfa sprouts-Michigan and Virginia, June-July 1997, Morb. Mortal. Wkly. Rep, 46, 741-744, 1997.

Dakshinamurty, S.: The common House-fly, Musca domestica, L., and its behaviour to temperature and humidity, B. Entomol. Res., 39, 339-357, 1948.

El-Fadel, M., Ghanimeh, S., Maroun, R., and Alameddine, I.: Climate change and temperature rise: Implications on food-and water-borne diseases, Sci. Total Environ., 437, 15-21, 2012.

Ferrano, S., Vancampenhoud, M., and Troncone, A.: Diarreas agudas en la edad pediátrica, XIV Jornadas Nacionales de Infectología y IX Jornadas Nororientales, Puerto La Cruz, Venezuela, $2-3,2003$.

Guerrant, R. L., Kosek, M., Moore, S., Lorntz, B., and Brantley, R.: Lima Am. Magnitude and Impact of Diarrheal Diseases, Arch. Med. Res., 33, 351-355, 2002.

Guzmán-Colis, G., Thalasso, F., Ramírez-López, E. M., RodríguezNarciso, S., Guerrero-Barrera, A. L., and Avelar-González, F. J.: Evaluación espacio-temporal de la calidad del agua del río San Pedro en el Estado de Aguascalientes, México, Rev. Int. Contam. Ambie, 27, 89-102, 2011.

Hernández, F. M.: Diarrea aguda e infecciones respiratorias: caras nuevas de viejos conocidos, Revista de la Facultad de Medicina UNAM, 45, 103-109, 2002.

Hernández, C. C., Aguilera, A. M. G, and Castro, E. G.: Situación de las enfermedades gastrointestinales en México, Enfermedades Infecciosas y Microbiología, 31, 137-151, 2011.
Hilborn, E. D., Mermin, J. H., Mshar, P. A., Hadler, J. L., Voetsch, A., Wojtkunski, C., Swartz, M., Mshar, R., Lambert-Fair, M. A., Farrar, J. A., Glynn, M. K., and Slutsker L.: A multistate outbreak of Escherichia coli O157: H7 infections associated with consumption of mesclun lettuce, Arch. Intern. Med., 159, 17581764, 1999.

INEGI: Instituto Nacional de Estadística y Geografía INEGI Censo de Población y vivienda 2010, available at: http://www3.inegi. org.mx/sistemas/mexicocifras/default.aspx?e=_1, last access: 21 February 2014, 2010.

INEGI: Instituto Nacional de Estadística y Geografía, Anuario estadístico y geográfico de Aguascalientes, available at: http://internet.contenidos.inegi.org.mx/contenidos/productos/ /prod_serv/contenidos/espanol/bvinegi/productos/anuario_14/ 702825064853.pdf (last access: 2 March 2016), 2014.

ISEA: Instituto de Salud del Estado de Aguascalientes, Estadísticas - Principales Causas de Mortalidad Infantil 2008-2014, Secretaría de Salud, available at: http://www.aguascalientes.gob.mx/ isea/mortinfa.asp, last access: 5 September 2014.

Konno, T., Suzuki, H., Katsushima, N., Imai, A., Tazawa, F., Kutsuzawa, T., Kitaoka, S., Sakamoto, M., Yazaki, N., and Ishida, N.: Influence of temperature and relative humidity on human rotavirus infection in Japan, J. Infect. Dis., 147, 125-128, 1983.

Loyola, R. and Soncco, C.: Salud y Calidad del Agua en Zonas Urbanomarginales de Lima Metropolitana, Economía y Sociedad, Cies, 64, 80-85, 2007.

NOAA: National Oceanic and Atmospheric Administration/Weather Service/Climate Prediction Center/historical El Niño/La Niña/Cold and Warm Episodes By Season, available at: http://www.cpc.ncep.noaa.gov/products/analysis_monitoring/ ensostuff/ensoyears.shtml, last access: 18 August 2014.

Patz, J. A. and Olson, S. H.: Climate change and health: global to local influences on disease risk, Ann. Trop. Med. Parasit., 100, 535-549, 2006.

Ramírez, E. M., Avelar, F. J., Zaragoza, J., and Rico, R.: Estudio sobre los agentes, cargas contaminantes y toxicidad que afectan el cauce del río San Pedro en el municipio de Aguascalientes y zonas aledañas, Informe final, Centro de Ciencias Básicas, Universidad Autónoma de Aguascalientes, Ags., México, 218 pp., 2007.

Ramírez-Castillo, F. Y., González, F. J. A., Garneau, P., Díaz, F. M., Barrera, A. L. G., and Harel, J.: Presence of multi-drug resistant pathogenic Escherichia coli in the San Pedro River located in the State of Aguascalientes, Mexico, Frontiers in microbiology, 4, doi:10.3389/fmicb.2013.00147, 2013.

Rose, J. B., Lisle, J. T., and LeChevallier, M.: Waterborne cryptosporidiosis: incidence, outbreaks, and treatment strategies, in: Cryptosporidium and cryptosporidiosis, edited by: Fayer, R., CRC Press, Boca raton, 93-110, 1997.

Schaffner, F. and Mathis, A.: Dengue and dengue vectors in the WHO European region: past, present, and scenarios for the future, Lancet Infect. Dis., 14, 1271-1280, 2014. 